\title{
CONSILIUM
}

Berkala Kajian Konseling Dan Ilmu Keagamaan

Avalaible at http://jurnal.uinsu.ac.id/index.php/consilium

ISSN : 2338-0608 (Print) | ISSN : 2654-878X (Online)

\section{Modifikasi Konseling Kelompok Untuk Siswa Dengan Pendekatan Rational Emotive Behavior Therapy (REBT) di Tengah Pandemi Covid-19}

\author{
Fauziah, Neviyarni, Yeni Karneli, Netrawati \\ Universitas Negeri Padang, Indonesia. \\ Korespondensi: fauziahridhwanteratai@gmail.com
}

\begin{abstract}
Guidance and Counseling Services is one of the services that can play an active role in the midst of this co-19 pandemic so students can adjust to conditions, in accordance with the rules set by the government, keep the spirit of learning and can control their stress and anxiety in a healthy manner. In this case the role of the BK teacher / school counselor is very important. However, various obstacles may arise in the learning process due to pandemic conditions that cannot be ascertained when it will end. This is a formidable challenge for school counselors / school counselors. One solution that can be done is to modify group counseling services using the Rational Emotive Behavioral Therapy (REBT) approach. In this article, we will discuss the modification of group counseling services for students with the Rational Emotive Behavioral Therapy (REBT) approach in the midst of the covid pandemic 19.
\end{abstract}

Keywords: Group counseling, Rational Emotive Behavioral Therapy (REBT), Covid-19.

\begin{abstract}
Abstrak: Layanan Bimbingan dan Konseling adalah salah satu layanan yang bisa berperan aktif di tengah pandemi covid-19 ini agar siswa bisa menyesuaikan diri dengan keadaan, sesuai dengan aturan yang ditetapkan oleh pemerintah, tetap semangat belajar dan bisa mengendalikan stres dan kecemasannya secara sehat. Dalam hal ini peran Guru BK/konselor sekolah sangatlah penting. Namun, berbagai hambatan bisa saja muncul dalam proses pembelajaran karena kondisi pandemi yang tidak bisa dipastikan kapan akan berakhir. Ini adalah tantangan berat bagi guru BK/konselor sekolah. Salah satu solusi yang bisa dilakukan adalah dengan memodifikasi layanan konseling kelompok menggunakan pendekatan Rational Emotive Behavioral Therapy (REBT) Pada artikel ini, kita akan membahas bentuk modifikasi layanan konseling kelompok untuk siswa dengan pendekatan Rational Emotive Behavioral Therapy (REBT) di tengah pandemi covid-19.
\end{abstract}

Kata kunci: Konseling kelompok, Rational Emotive Behavioral Therapy (REBT), Covid-19. 


\section{PENDAHULUAN}

$\mathrm{P}$

andemi Covid-19 yang tengah melanda dunia, termasuk kita di Indonesia, tidak jelas kapan akan berakhirnya (Covid-19: WHO Peringatkan Pandemi Virus Corona "masih Jauh" Dari Berakhir, Setelah Penambahan Kasus Harian Di Dunia Capai Angka Tertinggi, 2020). Sementara dampaknya dirasakan pada semua lini kehidupan manusia, termasuk pendidikan. Aturan pemerintah untuk stay at home, yang mengajak kita semua untuk beribadah dari rumah, belajar dari rumah dan bekerja dari rumah sudah mulai dilonggarkan asal tetap mengikuti protokol keluar rumah (Nugroho, 2020). Aturan keluar rumah jelas berlaku untuk semua anggota masyarakat termasuk siswa yang akan memasuki tahun ajaran baru. Jangan sampai kerinduan kembali menuntut ilmu di sekolah justru membuat mata rantai penyebaran covid-19 bertambah. Pemerintah dan Stake holder sekolah juga harus menyiapkan kondisi yang nyaman dan aman untuk siswa termasuk guru dan karyawan sehingga proses pembelajaran bisa berjalan (Ramdhani, 2020).

Pada dasarnya ketika manusia terganggu, mereka berpikir-merasabertindak dalam cara yang disfungsional, menyalahkan diri sendiri dan berpikir irasional. Dampaknya adalah mereka mengubah kognisinya, mengubah reaksi emosionalnya, dan mengubah aktivitasnya yang akan merugikan diri sendiri. Contoh: pandemi covid-19 membuat proses pembelajaran terganggu, proses belajar daring tidak sepenuhnya menyenangkan bagi siswa, di satu sisi ada kerinduan bertemu guru dan teman-teman di sisi lain mereka cemas tertular virus corona. Akibatnya siswa berpikir "seharusnya covid-19 tidak boleh terjadi, karena membuatnya memiliki banyak tugas dan PR", "covid-19 membuatnya takut ke luar kamar, takut keluar rumah karena harus memantau laptop melihat tugas yang diberikan guru, kalau waktunya mengumpulkan tugasnya lewat mereka tidak dapat nilai" (Aipassa, 2020; Riset Dampak Covid-19: Potret Gap Akses On Line "Belajar Dari Rumah" Dari 4 Provinsi, 2020). Ada siswa yang suka panik dan marah-marah kalau kesulitan mengerjakan soal, ada siswa yang tidak merasa kondusif mengerjakan tugas sekolah di rumah karena banyaknya gangguan (Jannah, 2020).

Bila merujuk pada beberapa kejadian yang dipaparkan di atas otomatis semua guru sudah harus mempersiapkan diri, bagaimana cara pelaksanaan proses pembelajaran di tengah pandemi untuk tahun ajaran baru. Termasuk guru BK/konselor sekolah yang akan memberikan layanan konseling kepada siswa. Kenyataan inilah yang harus dipahami oleh guru BK/konselor sekolah sehingga bisa mengkondisikan agar siswa tetap memiliki pemikiran yang rasional bahwa pandemi ini akan berakhir, sehingga mereka tetap semangat belajar, hasil belajarnya tetap optimal dan tidak perlu takut dengan banyaknya tugas atau PR, karena tugas atau PR membuat mereka tetap terus belajar walaupun dari rumah. 
Salah satu cara yang bisa dilakukan oleh guru BK/ konselor sekolah adalah dengan memodifikasi layanan, seperti layanan konseling kelompok dengan pendekatan Rational Emotive Behavioral Therapy (REBT). Tidak dipungkiri bahwa pelaksanaan di lapangan penggunaan pendekatan ini dalam konseling kelompok perlu kajian lebih dalam. Hal ini didasarkan atas fakta bahwa sebagaian besar konselor sekolah di Indonesia masih belum menerapkan basis pendekatan yang jelas dalam memberikan pelayanan konseling, terutama konseling kelompok (Afdal et al., 2019; Ardi et al., 2019; Hidayat et al., 2019; Illahi et al., 2018).

Layanan Bimbingan dan Konseling adalah salah satu layanan yang bisa berperan aktif di tengah pandemi covid-19 ini agar siswa bisa menyesuaikan diri dengan keadaan, sesuai dengan aturan yang ditetapkan oleh pemerintah, tetap semangat belajar dan bisa mengendalikan stres dan kecemasannya secara sehat. Terapis REBT membantu klien untuk mengubah kecemasan yang tidak sehat yang berasal dari keyakinan irasional. Dalam REBT, kecemasan dikonseptualisasikan sebagai emosi negatif yang tidak sehat karena mengarah pada fungsi maladaptif. Selain efek fisiologis yang tidak nyaman dan berpotensi tidak sehat (takikardia, ketegangan otot, gangguan pencernaan.dll) (Bernard \& Dryden, 2019).

Modifikasi layanan konseling kelompok ini bertujuan memudahkan guru BK/konselor sekolah memberikan layanan kepada siswa di tengah pandemi covid19. Jelas modifikasi diharapkan bisa tepat sasaran dalam penerapannya dengan kondisi proses pembelajaran di Indonesia. Sejatinya Layanan Konseling Kelompok dilaksanakan secara langsung, di suatu tempat yang telah disepakati bersama antara konselor dan anggota kelompok. Jumlah anggota kelompok beragam ratarata antara 5-10 orang, dipimpin oleh pemimpin kelompok (guru BK/konselor sekolah) dengan pola duduk melingkar dengan jarak yang dekat agar semua anggota kelompok bisa saling melihat anggota kelompok lainnya, sehingga interaksi dan dinamika kelompok bisa maksimal (Ardimen et al., 2018; Prayitno, 1995). Aturan ini tentu belum bisa sepenuhnya dilaksanakan karena kondisi pandemi covid-19 yang belum usai. Artikel ini membahas alternatif modifikasi pelaksanaan konseling kelompok untuk siswa dengan pendekatan Rational Emotive Behavioral Therapi (REBT) di tengan pandemi covid-19.

\section{METODE PENELITIAN}

Metode yang digunakan dalam penelitian ini adalah studi kepustakaan, yaitu studi yang objek penelitiannya bersumberkan pada kepustakaan baik berupa jurnal ilmiah, buku, artikel dalam media massa, maupun data-data statistika. Kepustakaan tersebut akan digunakan untuk memodifikasi layanan konseling kelompok di tengah pandemi virus Covid-19 dan bagaimana pelaksanaannya serta juga menjawab bagaimana kiat-kiat guru BK/konselor sekolah menjadi pemimpin kelompok. 


\section{HASIL PENELITIAN DAN PEMBAHASAN}

\section{Konsep Pendekatan Rational Emotive Behavioral Therapy (REBT).}

Terapi Rational Emotive Behavior Therapy (REBT) didasarkan pada suatu pemahaman bahwa manusia memiliki potensi kognisi, emosi, dan perilaku yang intrinsik terintegrasi dan holistik pada dirinya. Ketika manusia merasa, ia akan berpikir dan bertindak. Ketika manusia bertindak, ia merasakan dan berpikir. Ketika manusia berpikir, ia merasakan dan bertindak. REBT membantu manusia mengubah keyakinan irasional manusia menjadi keyakinan rasional sehingga meningkatkan fungsi emosi dan perilaku mereka (Ellis \& MacLaren, 2003). Manusia memiliki potensi berpikir yang rasional dan irasional. Inilah yang membuat manusia bisa melakukan kesalahan sekaligus bisa memperbaikinya atau berdamai dengan dirinya sendiri (Corey, 1995).

Terapi kelompok Rational Emotive Behavior Therapy (REBT) lahir pada tahun 1959, menggunakan model ABCDE. Albert Ellis menjelaskan bahwa dalam praktik terapi kelompoknya yang menggunakan REBT klien secara aktif berpartisipasi dalam memperdebatkan keyakinan irasional anggota kelompok lain dan mendiskusikannya atau memperdebatkannya sehingga semua anggota kelompok bisa mengambil manfaat dari perdebatan itu (Bernard \& Dryden, 2019). Rational Emotive Behavior Therapy (REBT) mengasumsikan bahwa ketika orang dihadapkan dengan peristiwa yang merugikan maka timbullah keyakinan irasional pada dirinya sehingga menghasilkan perasaan disfungsional dan perilaku maladaptif. Sedangkan keyakinan rasional akan menghasilkan perasaan fungsional dan perilaku adaptif. Artinya kepercayaan irasional adalah keyakinan, yang tidak memiliki dukungan logis, empiris dan fungsional, sedangkan keyakinan rasional adalah keyakinan, yang memiliki dukungan logis, empiris dan fungsional (Bernard \& Dryden, 2019).

Dapat dipahami bahwa tujuan utama REBT adalah: untuk membantu orang mengubah keyakinan irasional mereka ke keyakinan rasional dan dengan demikian meningkatkan fungsi emosi dan perilaku mereka selalu integratif (Ellis \& MacLaren, 2003). Sedangkan dalam konseling kelompok hasil akhir yang diinginkan adalah klien mengalami emosi negatif yang sehat, dalam hal ini, kekecewaan, kesedihan, daripada depresi. Anggota kelompok belajar untuk memisahkan keyakinan rasional (atau fungsional) mereka dari keyakinan irasional (atau disfungsional) mereka dan untuk memahami asal-usul gangguan emosional mereka serta dari anggota lainnya. Anggota kelompok diajarkan banyak cara agar mereka dapat : membebaskan diri dari filosofi hidup irasional mereka sehingga mereka dapat berfungsi lebih efektif sebagai individu dan sebagai makhluk relasional dan belajar cara-cara yang lebih tepat untuk merespons sehingga mereka tak perlu merasa terganggu dengan kenyataan hidup. Anggota kelompok saling membantu dan mendukung dalam upaya pembelajaran ini (Corey, 2012).

Guru BK/konselor sekolah sebagai pemimpin kelompok dalam layanan konseling kelompok dengan pendekatan Rational Emotive Behavior Therapy (REBT) memiliki empat fungsi, yaitu: pertama, menunjukkan kepada klien bahwa mereka memiliki pemikiran yang irasional yang tidak seharusnya terjadi. Kedua, membawa klien pada tahap kesadaran bahwa ia memiliki pemikiran yang irasional yang membuatnya terganggu. Ketiga, menolong klien memodifikasi 
pemikirannya. Keempat, menantang klien agar memiliki falsafah hidup yang rasional (Corey, 1995). Pelaksanaan layanan konseling kelompok melalui pendekatan Rational Emotive Behavior Therapy (REBT) memiliki beberapa tahap yang di kenal dengan ABCDE. Menurut Ellis tahapan ABCDE itu adalah:

$\mathrm{A}=$ mengaktifkan pengalaman (peristiwa yang sedang terjadi).

$\mathrm{B}=$ mewakili pendapat orang tentang pengalaman tersebut (keyakinan).

$\mathrm{C}=$ reaksi emosional terhadap $\mathrm{B}$ (konsekuensi emosi dan perilaku).

$\mathrm{D}=$ menjauhkan pemikiran irasional, biasanya dengan bantuan konselor REBT dan menggantinya dengan (intervensi yang meragukan / membantah).

$\mathrm{E}=$ pemikiran yang efektif dan filosofis pribadi baru yang akan membantu klien mencapai kepuasaan hidup yang lebih besar (efek) (Corey, 1995; Fearon et al., 2011; Glading, 2012).

Modifikasi pelaksanaan konseling kelompok dengan pendekatan Rational Emotive Behavior Therapy (REBT) yang bisa dilakukan guru $\mathrm{BK} /$ konselor sekolah dengan beberapa tahap, yaitu:

1. Tahap sosialisasi:

a. Kalau siswa di kelas itu belum pernah melaksanakan Konseling Kelompok guru BK/Konselor sekolah mensosialisasikan pelaksanaan Layanan Konseling Kelompok di grup Whatshapp (WA) kelas terlebih dahulu.

b. Gunakan WA semaksimal mungkin sebagai media tanya jawab dan diskusi, kapan perlu guru mengirimkan video atau link-nya pelaksanaan Layanan Konseling Kelompok. Guru harus piawai mempromosikan kalau Layanan Konseling Kelompok itu sangat berguna bagi siswa, berikan pemahaman pentingnya layanan dan berartinya layanan itu bagi siswa, jangan lupa beritahu siswa asyiknya berdiskusi dalam Layanan Konseling Kelompok

c. Pastikan siswa tertarik dan sukarela untuk ikut dalam kegiatan. Setelah itu bentuk kelompok dengan jumlah kelompok kecil 5-6 orang saja.

d. Bagi siswa yang sudah pernah melaksanakan Layanan Konseling Kelompok guru BK/Konselor sekolah tinggal mengajak mereka untuk sukarela ikut dalam kegiatan.

e. Sepakati waktu pelaksanaan kegiatan, pukul berapa dimulai dan diakhirnya, membudayakan tepat waktu dan menghargai durasi bicara yang efektif juga bisa langsung diterapkan oleh guru BK/konselor sekolah kepada siswa.

f. Laksanakan kegiatan Layanan Konseling Kelompok secara on line misalnya melalui aplikasi Skype, Zoom, FB Messenger.

g. Kerjasama dengan orang tua/wali siswa tentu sangat dibutuhkan untuk suksesnya layanan ini, izin orang tua/wali menggunakan 
aplikasi membuat siswa juga lebih nyaman untuk berbicara dalam kelompoknya.

2. Tahap pengajaran:

Mengajarkan dan mengajak siswa mempelajari gagasan dasar dari REBT, yaitu: siswa memahami bagaimana keyakinan mereka terhubung dengan emosi dan tingkah laku mereka. Prosedur ini bersifat instruktif dan mengarahkan siswa untuk terbuka dengan permasalahan yang dialaminya selama pandemi covid-19 ini. (A)

3. Tahap pertentangan:

Menentang keyakinan irasional siswa $(B+C+D)$. Salah satu cara yang paling efektif untuk membantu siswa mengurangi gangguan emosional mereka adalah dengan menunjukkan dan menyanggah keyakinan irasional mereka sampai mereka menyerah. Proses pertentangan ini melibatkan tiga langkah:

a. Mendeteksi kepercayaan irasional dan melihat bahwa keyakinan tersebut tidak logis dan tidak realistis.

b. Memperdebatkan keyakinan irasional ini dan menunjukkan kepada diri siswa bagaimana mereka tidak didukung oleh bukti.

c. Membedakan antara pemikiran irasional dan pemikiran rasional (Corey, 2012).

Pada bagian ini guru BK/konselor sekolah bisa menggunakan teknik konseling dalam REBT yaitu:

1) Teknik kognitif:

a) Cognitive disputation (dipute kognitif): mempertanya-kan keyakinan irasional

b) Pekerjaan rumah kognitif.

c) Mengubah gaya berbahasa seseorang.

d) Penggunaan humor.

2) Teknik emotif:

a) Imaginasi rasional emotif.

b) Bermain peran.

c) Latihan menyerang rasa malu.

d) Penggunaan kekuatan dan ketegaran.

3) Teknik behavioral:

a) Kondisioning operan.

b) Prinsip mengatur diri.

c) Disensitisasi sistematik.

d) Teknik bersantai.

e) Pemodelan (Corey, 1995). 


\section{Dorongan:}

Guru BK/konselor sekolah mendorong siswa menggunakan keyakinan yang rasional dan mengkonfrontasi siswa bila guru BK/ konselor sekolah menilai siswa mengaku sudah berpikir rasional padahal sebenarnya belum.

4. Setelah D muncul E atau pengaruh pertentangan.

Pelepasan keyakinan irasional siswa yang merusak sehingga siswa memperoleh keyakinan baru yang rasional.

\section{KESIMPULAN}

Sebagai sebuah pendekatan dalam layanan konseling kelompok maka pendekatan Rational Emotive Behavior Therapy (REBT) diasumsikan bisa dimodifikasi untuk diterapkan dalam rangka optimalisasi proses pembelajaran dan hasil belajar siswa di tengah pandemi covid-19. Hal ini didasarkan atas kemampuan pendekatan ini dalam melakukan mengubah keyakinan irasional siswa menjadi rasional.

\section{DAFTAR PUSTAKA}

Afdal, A., Alizamar, A., Ifdil, I., Sukmawati, I., Zikra, Z., \& Ilyas, A. (2019). An Analysis of Phubbing Behaviour: Preliminary research from counseling perspective. International Conference on Educational Sciences and Teacher Profession (ICETeP 2018), 295, 270-273.

Aipassa, J. (2020). Libur karena Corona, Siswa DKI Kangen Sekolah Normal. Beritasatu.Com. https:/ / www.beritasatu.com/megapolitan/611013/liburkarena-corona-siswa-dki-kangen-sekolah-normal

Ardi, Z., Neviyarni, N., Karneli, Y., \& Netrawati, N. (2019). Analisis pendekatan Adlerian dalam konseling kelompok untuk optimalisasi potensi diri siswa. Jurnal EDUCATIO: Jurnal Pendidikan Indonesia, 5(1), 712.

Ardimen, Natalia, D. Y., Tas'adi, R., \& Dovita, R. (2018). Efektivitas Layanan Bimbingan Kelompok Terhadap Kualitas Interaksi Sosial Anak Asuh. Jurnal Edukatif: Journal of Educational Studies, 3(2).

Bernard, M. E., \& Dryden, W. (2019). Advances in REBT. Springer Nature Switzerland.

Corey, G. (1995). Teori dan Praktek dari Konseling dan Psikoterapi. Broks/Cole Publishing Company Pacific Grove.

Corey, G. (2012). Theory \& Praktice of Group Counseling. Thomson Higher Education 10 Davis Drive.

Covid-19: WHO peringatkan pandemi virus corona "masih jauh" dari berakhir, setelah penambahan kasus harian di dunia capai angka tertinggi. (2020). BBC News Indonesia. https://www.bbc.com/indonesia/dunia-52749155 
Ellis, A., \& MacLaren, C. (2003). Rational Emotive Behavior Therapy A Therapist's Guide. Published by Impact Publisher.

Fearon, C., Starr, S., \& McLaughlin, H. (2011). Value of blended learning in university and the workplace: Some experiences of university students. Industrial and Commercial Training, 43(7), 446-450. https:/ / doi.org/10.1108/00197851111171872

Glading, S. . (2012). Konseling Profesi yang Menyeluruh. Index.

Hidayat, H., Ardi, Z., Herawati, S., \& Amrina, Z. (2019). The Contribution of Internal Locus of Control and Self-Concept to Career Maturity in Vocational Higher Education. The First International Conference on Education, Science and Training: Empowering Educational Human Resources for Global Competitiveness, 2019, 234-248. https:/ / doi.org/10.18502/kss.v3i15.4370

Illahi, U., Neviyarni, S., Said, A., \& Ardi, Z. (2018). Hubungan antara kecerdasan emosi dengan perilaku agresif remaja dan implikasinya dalam bimbingan dan konseling. JRTI (Jurnal Riset Tindakan Indonesia), 3(November), 68-74.

Jannah, S. M. (2020). Segudang Masalah Belajar dari Rumah karena Corona COVID19. Tirto.Id. https://tirto.id/segudang-masalah-belajar-dari-rumahkarena-corona-covid-19-eGqQ

Nugroho, A. (2020). No Title. Ugm.Ac.Id. https://ugm.ac.id/id/berita/19463sosiolog-ugm-infrastruktur-protokol-kesehatan-prasyarat-utama-the-newnormal

Prayitno. (1995). Buku Seri Bimbingan dan Konseling di Sekolah: Bimbingan dan konseling kelompok (dasar dan profil). Ghalia Indonesia.

Ramdhani, G. (2020). Menteri Nadiem Tegaskan Keputusan Masuk Sekolah Ada di Gugus Tugas Covid-19. Liputan6.Com. https:/ / www.liputan6.com/news/read/4263635/menteri-nadiemtegaskan-keputusan-masuk-sekolah-ada-di-gugus-tugas-covid-19

Riset Dampak Covid-19: Potret Gap Akses On Line "Belajar Dari Rumah" Dari 4 Provinsi. (2020). Theconversation.Com. https:/ / theconversation.com/risetdampak-covid-19-potret-gap-akses-online-belajar-dari-rumah-dari-4provinsi-136534 